On each evening of the celebrations, for the first time in the history of St. Andrews, certain of its picturesque buildings were floodlit: these included St. Salvator's Chapel, the United College, the romantic ruins of the Castle and Cathedral, Holy Trinity
Church and the West Port. Altogether, the fame that St. Andrews has won as an unsurpassed setting for charming and dignified academic ceremonials has never been better justified than on this memorable occasion in the long history of the University.

\title{
OBITUARIES
}

Field Marshal the Right Hon. J. C. Smuts, O.M., C.H., F.R.S.

$I_{N}$ the course of a long and exceptionally active life, Smuts acquired an outstanding reputation as lawyer, soldier, statesman, writer and philosopher. It would have been surprising if a man so versatile had been lacking in appreciation of those advances in the knowledge and practical application of science which have been perhaps the most distinctive feature of the age in which he lived : nor, indeed, was he. He had, I think, no technical training in scientific matters; but I can testify that he followed developments elosely and was keenly alive to the social and economic implications of recent scientific discoveries and to their bearing on international relations.

I had many talks with him during the War about the significance of the work on nuclear energy to which so much time and money were being devoted, and $I$ had the opportunity in that connexion of introducing him to Prof. Niels Bohr, whose distinguished record was already familiar to him and of whom he had become an ardent admirer. Thereafter they had many discussions together in my presence. Smuts was thrilled by the possible economic significance of the discovery of vast quantities of low-grade uranium ore in the gold-bearing formations of the Rand. In quite another connexion I found that he had been following with the liveliest interest the recent spectacular discoveries demonstrating the South African origin of the earliest known forms of prehistoric man.

It is, however, in the argument by which Smuts developed the philosophical conception to which he applied the term 'holism' that one finds the clearest evidence of his extensive knowledge and understanding of the course of recent scientific researches. In successive chapters he sets out in non-technical language the basic theories of atomic structure, relativity, the doctrine of the space-time continuum, quantum theory, cell structure, Mendelism and much else. All this collated information serves to sustain his first main contention that the chief gaps in human knowledge are those which separate the phenomena of matter, life and mind, and leads up to, without establishing, his suggestion that in the grand design of the universe there must be an essential unity. From this, two broad conclusions emerge. The mysteries of life and mind may perhaps, when the key has been discovered, be unravelled in the same way as the mysteries of matter ; and, while humanity may pass through a "series of vast secular crises", and may be passing through such a period now, all will eventually develop according to the master plan of the Creator. Incidentally, in the absence of knowledge of that master plan, mere human planning will be largely vain, as Smuts more than hinted in his inaugural speech as Chancellor of the University of Cambridge. His faith was ardent, and such was its basis.
In all discussions, military, political or philosophical, the serenity of the man's mind was remarkable. It is, indeed, a tragedy that at this juncture the world should be deprived of his wise, kindly and courageous counsel. JoHN ANDERSON

\section{Prof. H. Gordon Jackson}

Brrkbeck College, the University of London and zoological circles have suffered a sad loss by the recent death in a road accident of Harold Gordon Jackson, master of the College and professor emeritus of zoology in the University. Born in Sussex in 1888, he passed his early days in Liverpool, attending Merchant Taylors' School and the University of Liverpool. When qualified, he was appointed research assistant to Sir William Herdman, and spent much time at the Marine Laboratory, Port Erin, and at sea on Herdman's yacht, so acquiring a fondness for marine biology and Crustacea which characterized his later zoological work. In 1913 he was appointed to a lectureship at the University of Birmingham; but the tenure of this was interrupted by service with the Royal Warwickshire Regiment during the First World War.

A long association with the University of London was begun in 1921, when Jackson was appointed reader and head of the Zoology Department at Birkbeck College, newly admitted by the Senate as a school of the University. From that date he played an outstanding part in the development of the Department of Zoology and of the College itself, so that in 1941, when an acting master was required, he was the obvious choice; on Sir John Maud's resignation in 1943, he was persuaded-much against his will, for it meant a cessation of zoological work-to accept the mastership. Started reluctantly, as it was, and at a time when war dangers made the very physical existence of the College a continuous hazard, his period of mastership was an immense personal success. The University pressed the excellent administrator that he proved to be into service in many capacities, so that at the time of his death Prof. Jackson was deputy vice-chancellor, chairman of the Academic Council and a governor of four of its schools. Other bodies, too, gladly took advantage of his skill, and he was, at one time or another, on the Council of the Association of British Zoologists, the Council for the Promotion of Field Studies, the Freshwater Biological Association and the Marine Biological Association.

Prof. Jackson's scientific work was almost entirely concerned with Crustacea, in later years predominantly with the systematies of land isopods, on which he published many important papers. But zoology was only one of many things in which he was deeply interested: music, architecture and literature all occupied his attention, and he could talk as understandingly to his Faculty of Arts as to his Faculty of Science. The main appeal of these (another link with 
Herdman) was antiquarian-it was classical music, old castles and churches that aroused his keenest interest, and one would often find him reading some eighteenth-century writer in the 'tube train' on his way to College. Prof. Jackson's main success was, however, personal, and it is in this that his old students and colleagues will remember him-the kindly interest he took in their schemes, great or small; the touches of humour and the deft similes with which he enlivened his lectures; the breadth of his sympathies for, and the wise and tolerant attitude to, the endless succession of activities that make up the daily life of $a$ thriving university college.

A. Graham
WE regret to announce the following deaths :

Sir William Benham, K.B.E., F.R.S., emeritus professor of biology in the University of Otago, on August 21, aged ninety.

Prof. Costantino Gorini, correspondant for the Section of Rural Economy of the Paris Academy of Sciences and formerly professor of agricultural bacteriology in the Istituto Superiore Agrario, Milan, on September 3, aged eighty-five.

Prof. E. A. Milne, M.B.E., F.R.S., Rouse Ball professor of mathematics in the University of Oxford, on September 21, aged fifty-four. land.

\section{NEWS and VIEWS}

\section{Use of the Term 'Vitamin P'}

AT the meeting of the Federation of American Societies for Experimental Biology in Atlantic City, April 17-21, 1950, the following recommendation of the Joint Committee on Biochemical Nomenclature of the American Society of Biological Chemists and the American Institute of Nutrition was adopted: "The term 'vitamin P' was first applied to a substance present in lemon juice. It was said to be effective in reducing the extent of hæmorrhages and extending the duration of life in scorbutic guifea pigs and was also proposed for the treatment of vascular purpura. Subsequent studies have failed to substantiate these claims, and the identity of a substance of a vitamin nature has not been established. Continued applica. tion of the term 'vitamin P' to one or another of a group of polyphenolic substances will lead only to confusion. It is therefore recommended that the term 'vitamin $\mathbf{P}$ ' should no longer be employed."

\section{Study of Statelessness}

THE United Nations Department of Social Affairs has issued "A Study of Statelessness" (pp. xiii +190. Lake Success, N.Y.: United Nations ; London : H.M. Stationery Office, 1949. 1.25 dollars; 9s.), which presents a general survey of national legislation and international agreements relating to stateless persons, and indicates the main systems in force. The survey, which was made at the request of the Economic and Social Council, considers both the improvement of the status of stateless persons and the elimination of statelessness. The former, however, only offers a temporary solution, and the real goal is the elimination of statelessness. As a preliminary measure, the study recommends that States be invited to refrain from taking discriminatory measures against stateless persons in territories under their jurisdiction and to deal with them in accordance with the Conventions of 1933 and 1938. It is also recommended that, in consultation with the International Refugee Organisation and other specialized agencies concerned, a fresh convention be drafted which would include provisions concerning such subjects as personal status, property rights, the exercise of trades and professions, education, a travel document taking the place of a passport, the procurement of documents enabling stateless persons to perform various acts of civil and administrative life, entry, sojourn and expulsion. To eliminate the source of statelessness the study further recommends that every child should receive a nationality at birth and that no person throughout his life should lose his or her nationality until he or she has acquired a new one. Certain principles are also suggested for reducing the number of existing cases of statelessness.

\section{British Institute of Management}

IN his chairman's address at the annual general meeting of the British Institute of Management on July 26, Sir Charles Renold said that in little more than two years remarkable progress had been made in getting the Institute established as a national organisation. Its conferences, which are meeting a definite need, have been a major factor to this end. Besides the absorption of the British Management Council and the Confederation of Management Associations and the projected merger with the Institute of Industrial Administration, a further measure of co-ordination is being achieved by the contacts facilitated by the accommodation of various bodies with the Institute at Management House. The goodwill of Industry and British Managernent Review has been purchased by Management Publications, Ltd., and, under the new title The Manager, the former is being developed as the organ of British management. The Information Service of the Institute is constantly developing, and a series of specialist handbooks is in preparation. A handbook giving full details of the national scheme for intermediate certificates in management studies, which the Institute is conducting in conjunction with the Ministry of Education and the Scottish Education Department, is to be issued, and a subcommittee has been studying the whole question of foremanship training in technical colleges.

Sir Charles referred in some detail to the considerations which have led the Council of the Institute to conclude that the time is now ripe for the Institute to set about the development of professional qualifications in general management as the basis for building a professional membership. The Council recognizes that such professional qualifications are desirable only in so far as they can establish themselves with industry as significant indications of capacity to undertake general management responsibility, and that an indispensable element in granting such qualifications is an assessment of personal qualities. It is intended to make it clear from the outset that the Institute is building for the future, and that its primary concern is with the young manager. Arrangements will nevertheless be made for senior managers, whose practical achievements merit recognition, to be associated with the Institute, for example, in a separate 'transitional' category of professional 